\title{
Two Independent Value Orientations: Ideal and Counter-Ideal Leader Values and Their Impact on Followers' Respect for and Identification with Their Leaders
}

\author{
Matthias M. Graf • Niels Van Quaquebeke • \\ Rolf Van Dick
}

Received: 25 December 2010/ Accepted: 9 May 2011/Published online: 31 May 2011

(C) The Author(s) 2011. This article is published with open access at Springerlink.com

\begin{abstract}
Traditionally, conceptualizations of human values are based on the assumption that individuals possess a single integrated value system comprising those values that people are attracted by and strive for. Recently, however, van Quaquebeke et al. (in J Bus Ethics 93:293-305, 2010) proposed that a value system might consist of two largely independent value orientations - an orientation of ideal values and an orientation of counter-ideal values (values that individuals are repelled by), and that both orientations exhibit antithetic effects on people's responses to the social world. Following a call for further research on this distinction, we conducted two studies to assess the independent effects of ideal and counter-ideal values in leadership settings. Study $1(N=131)$ finds both value orientations to explain unique variance in followers' vertical respect for their leaders. Study $2(N=136)$ confirms these results and additionally shows an analogous effect for followers' identification with their leaders. Most importantly, we find that both value orientations exhibit their effects only
\end{abstract}

M. M. Graf

Kienbaum Management Consultants $\mathrm{GmbH}$,

Potsdamer Platz 8, 10117 Berlin, Germany

e-mail: matthias.graf@kienbaum.de

M. M. Graf · R. Van Dick

Psychology Department, Goethe University Frankfurt,

Kettenhofweg 128, 60054 Frankfurt, Germany

R. Van Dick

e-mail: van.dick@psych.uni-frankfurt.de

N. Van Quaquebeke $(\square)$

Management Department, Kuehne Logistics University - The

KLU, Brooktorkai 20, 20457 Hamburg,

Germany

e-mail: niels.quaquebeke@the-klu.org independently when the content of the two orientations pertain to different value types in Schwartz's (in J Soc Issues 50:19-46, 1994) circumplex model. Implications for theory and practice are discussed.

Keywords Ideal values · Counter-ideal values · Leadership · Respect for leaders · Identification with leaders

\section{Introduction}

Human values shape our personal, social, and professional lives by signaling desirable ways of behaving as well as ideal end states (Rokeach 1973; Schwartz 1992). As such, values profoundly affect people's attitudes (Maio and Olson 1994) and behaviors (Verplanken 2004; Verplanken and Holland 2002) toward the social world. Recently, there has been a resurgence of research on topics such as values, value congruence, and value leadership (e.g., Posner 2010; Suar and Khuntia 2010; van Quaquebeke et al. 2009).

Research from different areas of psychology, however, increasingly finds that people are not only driven by appetitive forces they are attracted to, but also by aversive forces they are repelled by (see Carver et al. 2000). The theoretical and empirical distinction between these orientations is noted in many theories regarding human nature, such as, for instance, dispositional theory (Cattell 1957), social-cognitive theory (Rotter 1954), and cognitive theory (Heider 1958). Surprisingly, however, this notion of opposing psychological forces seems to be largely absent from value research. One notable exception is the recent study by van Quaquebeke et al. (2010), who argue that human value systems comprise two types of value-orientations, one that is appetitive and one that is aversive. They propose that both 
are independently informative for people's attitudes and behavior, and, based on first empirical evidence, conclude that it would be premature to assume that the content of one value orientation reflects the mere opposite of the other. Instead, they can be thought of as two independent layers. Indeed, van Quaquebeke and colleagues' results confirm that the degree to which leaders are perceived to represent values of both orientations, i.e., followers' ideal and counter-ideal leader values, simultaneously and independently affect followers' identification and satisfaction with those leaders. However, the authors also caution that their findings should be considered preliminary because they only used single item measures to assess the degree to which a leader matched participants' ideal and counter-ideal leader values. It is thus not clear whether the contents of both value orientations are related. Moreover, it is unclear whether their contents may include important boundary conditions that may explain when and why a leader's congruence with both value orientations exhibit independent effects on followers' responses toward that leader.

In the present study, we aim at a more in-depth investigation of the importance of both value orientations in the context of leader-follower relationships. Following van Quaquebeke et al. (2010), we seek to test whether the independent forces of ideal and counter-ideal values on followers' responses toward their leaders can be replicated using a more complex value instrument such as the Portrait Values Questionnaire (PVQ; Schwartz 2005, 2006). Second, we seek to investigate whether the predictive value of both value orientations for followers' responses toward their leaders depends on the degree of content independence of both value orientations. In doing so, we not only seek to enrich the current literature on human values, but also inform practice with regard to how value statements should be made and how they can be improved by taking both value orientations into account.

\section{Two Value Orientations}

The nature of human values has always been of great research interest. As a result, many different conceptualizations of values have been proposed and explored. Overall, researchers agree that values either describe desirable ways of behaving or ideal end states (Rokeach 1973; Schwartz 1992). Building on these views, research has shown that values function as important bridging constructs between different aspects of personality and attitudes (Olson and Maio 2003; Yik and Tang 1996), and are among the most important predictors of attitudes and behavior in all areas of life, including work contexts (Bardi and Schwartz 2003; Hemingway and Maclagan 2004; Maio and Olson 1995; Meglino and Ravlin 1998).
The most commonly applied framework for understanding value systems stems from Schwartz (1992,1994). He found that values can be organized by 10 general value types: universalism, benevolence, tradition, conformity, security, power, achievement, hedonism, stimulation, and self-direction. Each value type is characterized by a central motivational goal and the pursuit of any two of these goals can either be compatible or incompatible. Based on these assumptions, Schwartz proposed a circumplex model, in which motivationally compatible value types lie next to each other, whereas motivationally incompatible value types appear opposed to each other. Essentially, Schwartz suggested that the ten value types can be organized along two orthogonal bipolar dimensions (i.e., value types of higher order): the first dimension contrasts the poles selftranscendence and self-enhancement, whereas the second dimension contrasts the poles conservation and openness to change. According to this framework, people differ in terms of the subjective and relative importance they place on each value type and thus in terms of the dynamic organization of the priorities in their value systems (cf. Rohan 2000).

However, recent insights from research on attitudes and beliefs suggest that values might differ not only with regard to their importance and organization but also with regard to their reflections of the positive or negative motivational goals that underlie them (Maio et al. 2003). In other words, values might not always be desirable ways of behaving or ideal end states; some values might be undesirable ways of behaving and counter-ideal end states that individuals try to avoid. In that sense, like attitudes, values reflect positivity or negativity toward an object of evaluation. Indeed, attitudes serve a value-expressive function: people tend to like objects that promote their values and dislike objects that threaten their values (Katz 1960; Maio and Olson 1995). Kaplan (1972) thus proposed that individuals display two distinct types of attitudes: one that subsumes an evaluation that varies in negativity, and one that subsumes an evaluation that varies in positivity. Consistent with this reasoning, Rodin (1978) argued that people represent degrees of liking and disliking of objects along separate dimensions of evaluation. In addition, Cacioppo and colleagues (e.g., Cacioppo and Berntson 1994; Cacioppo et al. 1997) proposed that positive and negative evaluative processes involve distinct classes of antecedents and consequences. As values underlie cognitive networks of attitudes and beliefs, it follows that these can also reflect both positive and negative behaviors or end states. Based on van Quaquebeke et al.'s proposal (2010), we specifically seek to investigate whether the two value orientations can be differentiated with regard to leadership.

Hypothesis 1 Followers' representation of ideal and counter-ideal leader values are empirically distinct. 


\section{Leaders Representing Followers' Value Orientations}

Leadership has been defined in many ways. One of the most prominent definitions stems from Yukl who views leadership as process of influence (2010). When defined in this way, the concept of influence and the means by which it is achieved are put centerstage. As such, it is important to understand how leaders exert influence beyond positional forms of power, i.e., how their leadership (and not management) becomes effective. It has been suggested that leaders are most effective and respected when their values are congruent with the values that their followers cherish, and vice versa (see Dvir et al. 2002; Lord and Brown 2001). Incongruence between leaders' and their followers' values, by contrast, can be a source of major conflict or ambiguity for employees.

Assuming that value systems comprise both ideal and counter-ideal values, we propose that both value orientations simultaneously influence followers' responses toward their leaders, in particular those responses that signal a certain openness and accordance with the leader such as followers' vertical respect for (van Quaquebeke et al. 2007) and identification with their leaders (van Dick et al. 2004). Indeed, people are likely to use both value orientations to assess the amount of congruence between their value systems and the value systems represented by their leaders. This dual evaluation enables followers to judge their leaders more completely and ultimately to decide how much they are attracted to or repelled by their leaders.

Hypothesis 2 The more followers perceive their leaders to represent their ideal values in the leadership domain, the more they respect (and identify with) their leaders.

Hypothesis 3 The more followers perceive their leaders to represent their counter-ideal values in the leadership domain, the less they respect (and identify with) their leaders.

Hypothesis 4 Followers' perceptions of their leader's congruity both with their ideal leader values and with their counter-ideal leader values simultaneously and independently predict followers' respect (and identification with) their leaders.

Furthermore, we assume that the size of these effects depends on the degree of overlap in the contents of the two value orientations. If the mental representations of two distinct concepts are so similar that they form the same representation from different angles, the effects of one are inherent in the other (cf. Aron et al. 1991; Smith et al. 1999). Under such circumstances, one value orientation would already capture the effect of the other value orientation.
In this respect, van Quaquebeke et al. (2010) assume that people are likely to vary in the degree to which their ideal and counter-ideal values represent the same dimension versus different dimensions. Hence, if counter-ideal values are mentally represented as dimensionally distinct from ideal values, they are likely to have additional influence on peoples' attitudes and behaviors. However, van Quaquebeke and colleagues were not able to test this assumption, because they only used a single item measure and thus could not map specific values upon the circumplex model to interpret their dimensionality.

Hypothesis 5 The more distinct followers' ideal and counter-ideal values are from each other, the more the leader's congruity with both value orientations will influence followers' respect for and identification with their leaders.

\section{Overview of Studies}

To test our hypotheses, we conducted two survey studies. Study 1 explores whether a leader's match with ideal and counter-ideal leader values independently inform followers' respect for the leader. Study 2 aimed at replication and furthermore extends Study 1 by exploring whether ideal and counter-ideal leader values have the same effects on another central variable in organizational behavior research: followers' identification with their leader.

\section{Study 1}

\section{Method}

\section{Participants}

To obtain a heterogeneous sample of employees, we recruited participants via a German online panel (www. sozioland.de). Online panels consist of people who have all agreed to participate in online surveys and who have been thoroughly checked by the panel provider. This enables researchers to access a pool of people who are not only willing but also used to filling in online surveys-thereby increasing the quality of response data. A total of 131 participants completed the survey. All of the participants indicated that they reported to a specific leader. A slight majority of the sample was female (57\%). Average age was 37.94 years $(S D=9.80)$. Almost $41 \%$ of participants had a university or college degree. Around $60 \%$ of participants had completed professional or vocational training. Total work experience (i.e., time in employment after completion of first degree) averaged 16 years $(S D=10.22)$ with an average of five personally experienced leaders $(S D=$ 
3.68 ), of whom an average of $24 \%$ were female. Overall, participants were employed across more than 20 different industries.

\section{Measures}

To measure the degree to which participants perceived their leaders to match their ideal and counter-ideal leader values, we asked participants to fill in the Portrait Value Questionaire (PVQ; Schwartz 2005, 2006; see also Schwartz et al. 2001) adapted to the work context. The PVQ Short includes 21 verbal portraits (Bilsky et al. 2010; Schwartz et al. 2001), each describing a person's aspirations in a way that implicitly points to the personal importance of a certain value type of the circumplex model. Each participant had to complete the PVQ thrice. In one version, participants were asked to what extent the person described in each portrait resembled their ideal leader. In the second version, participants were asked to what extent the person described in each portrait resembled their counter-ideal leader. In the final version, they were asked to what extent the person described in each statement resembled their current leader. The three versions were presented in random order to participants, and the 21 portraits were also presented randomly.

Originally, the PVQ is presented using a six-point Likert response scale, ranging from "not like me at all" to "very much like me." However, we reformulated the categories to match the three questions described above. We also added a neutral midpoint to form a seven-point Likert scale (cf. Krosnick and Fabrigar 1997; Krosnick and Presser 2010; O'Muircheartaigh et al. 1999), as it has been shown that the reliability of scales increases with the number of answer alternatives (Alwin 2010; Alwin and Krosnick 1991). Krosnick and Presser (2010) concluded that the use of seven-point scales provides several conceptual and methodological advantages, such as an adequate transformation of people's mental representations of concepts and a homogenous distribution of responses.

The outcome variable, participants' vertical respect for their leaders, was measured using van Quaquebeke and Brodbeck's (2008; see also van Quaquebeke et al. 2011) six-item scale. The scale reflects the extent to which followers voluntarily accept and seek their leader's influence, using items such as "I trust the judgment of my leader in work issues" and "At work I enjoy being able to learn from my leader." Each participant rated each item on a five-point Likert scale, ranging from "not at all" to "very much."

\section{Analyses}

We first computed scales that reflected the four higherorder value types: self-transcendence, self-enhancement, openness to change, and conservation. To assess the leader's congruence on both value orientations, we computed Euclidean distances (cf. Danielsson 1980) between followers' ideal leader values and their perceived current leader values as well as between followers' counter-ideal leader values and their perceived current leader values for each of the four higher-order value types. Next, we summed the difference scores to compute two overall scores: (a) congruence between the ideal and current leader values and (b) congruence between the counter-ideal and current leader values.

To test the Hypotheses 1 through 4, we conducted a twostep multiple regression analysis. In the first step, we included the standardized congruence score between the current and the ideal leader to test its influence on followers' respect for their current leaders (Hypothesis 2). In the second step, we added the respective counter-ideal to current leader congruence score to test whether it would appear as distinct from the ideal-current congruence score (Hypothesis 1) and independently affect followers' respect for their current leaders (Hypotheses $3+4$ ). To test Hypothesis 5, we split the sample at the mean of the congruence score (i.e., reverse Euclidian distance) of followers' ideal and counter-ideal leader values and recalculated the regression analyses within the two subsamples.

\section{Results}

Table 1 provides descriptives and scale intercorrelations. Note that when we speak of congruence, we refer to the opposite of the Euclidian distance displayed in the tables. As shown in Table 1, the overall scores for ideal and current leader values are positively associated $(r=0.55$, $p<0.01)$. While this relationship is significant and substantial, it is not surprising and can be subject to the confirmatory bias phenomenon, in which peoples' perceptions of an object (e.g., their current leader) are similar to their expectations and knowledge structures (e.g., ideal leader) (e.g., Snyder and Cantor 1979; Snyder and Swann 1978a, b). Moreover, the overall scores for ideal and counter-ideal leader values correlate negatively $(r=-0.35, p<0.01)$, as expected. Importantly, the amount of shared variation is only $12 \%$, which leaves room for unique contributions with respect to our main hypotheses (cf. van Quaquebeke et al. 2010). Hypothesis 1 is thus supported.

To test whether the congruence scores (between the ideal and current leader values as well as between the counter-ideal and current leader values) exhibit independent effects, we used a two-step multiple regression analysis and analyzed the effects on participants' respect for their leaders while simultaneously entering the leader's match of ideal values and the leader's match of counterideal values. Table 2 shows that both predictors remain 
Table 1 Descriptive statistics and correlations for Study $1(N=131)$

\begin{tabular}{|c|c|c|c|c|c|c|c|c|c|}
\hline & $M$ & $S D$ & 1 & 2 & 3 & 4 & 5 & 6 & 7 \\
\hline 1. Ideal leader & 4.85 & 0.54 & $(0.72)$ & - & - & - & - & - & - \\
\hline 2. Counter-ideal leader & 3.43 & 0.75 & $-0.35 * *$ & $(0.80)$ & - & - & - & - & - \\
\hline 3. Actual leader & 4.57 & 0.63 & $0.53 * *$ & -0.13 & $(0.70)$ & - & - & - & - \\
\hline 4. $(\text { Ideal leader }- \text { Actual leader })^{2}$ & 8.96 & 12.05 & -0.11 & 0.04 & $-0.39 * *$ & $(-)$ & - & - & - \\
\hline 5. $(\text { Counter-ideal leader }- \text { Actual leader })^{2}$ & 20.70 & 16.88 & $0.33 * *$ & $-0.54 * *$ & $0.46 * *$ & $-0.34 * *$ & $(-)$ & - & - \\
\hline 6. $(\text { Ideal leader }- \text { Counter-ideal leader })^{2}$ & 30.57 & 17.65 & $0.40 * *$ & $-0.58 * *$ & $0.19 *$ & $0.20 *$ & $0.73 * *$ & $(-)$ & - \\
\hline 7. Respect for leader & 3.26 & 0.96 & 0.03 & -0.09 & $0.41 * *$ & $-0.68 * *$ & $0.43 * *$ & -0.03 & $(0.89)$ \\
\hline
\end{tabular}

Note: Cronbach's alphas are indicated in parentheses

$* p<0.05$. ** $p<0.01$

significant when simultaneously entered into the regression equation. In addition, the $R^{2}$ change between step 1 and step 2 is significant for respect for leader, suggesting that the addition of a leader's match of counter-ideal leader values explains a unique amount of variance beyond a leader's match of ideal leader values (cf. van Quaquebeke et al. 2010). Thus, Hypotheses 2, 3, and 4 are also supported.

To assess whether the obtained effects can be explained by content overlap between ideal and counter-ideal values, we split our sample and divided the participants into those whose ideal and counter-ideal values showed minor differences in content and those whose ideal and counter-ideal values showed major differences in content, as described in the above 'analysis' section $\left(n_{1}=62 ; n_{2}=69\right)$. Next, we calculated the previous regression analyses again but separately for each subsample. For the subsample where the Euclidean distance between ideal and counter-ideal values is low (i.e., high congruence), Table 3 shows that only the leader's match of ideal values remains significant when both predictors are simultaneously entered into the regression equation. In addition, the $R^{2}$ change between step 1 and step 2 appears not to be significant, suggesting that the addition of a leader's match of counter-ideal leader values does not explain a unique amount of variance beyond his or her match of ideal leader values. By contrast, both predictors remain significant when simultaneously entered into the regression equation for the subsample where the Euclidean distance between ideal and counter-ideal values is high (i.e., low congruence). In addition, the $R^{2}$ change between step 1 and step 2 is significant, suggesting that the addition of a leader's match of counter-ideal leader values explains a unique amount of variance beyond his or her match of ideal leader values when participants' ideal and counter-ideal values include substantially different contents. Thus, Hypothesis 5 is also supported.

\section{Study 2}

The purpose of Study 2 is twofold: first, we want to replicate the findings of Study 1 in an independent sample. Second, we want to show that the effects not only hold for followers' respect for their leaders but also for followers' identification with their leaders (Mael and Ashforth 1992; van Dick et al. 2004).

Table 2 Results of multiple regression analysis of respect for leader on squared differences between ideal leader and actual leader, and counterideal leader and actual leader in Study $1(N=131)$

\begin{tabular}{|c|c|c|c|c|}
\hline Respect for leader & $B$ & SE $B$ & $\beta$ & \\
\hline \multicolumn{5}{|l|}{ Step 1} \\
\hline$(\text { Ideal leader }- \text { Actual leader })^{2}$ & -0.66 & 0.06 & $-0.68 * *$ & \\
\hline$\Delta R^{2}$ & & & & 0.46 \\
\hline$\Delta F$ & & & & $111.60 * *$ \\
\hline \multicolumn{5}{|l|}{ Step 2} \\
\hline$(\text { Ideal leader }- \text { Actual leader })^{2}$ & -0.58 & 0.06 & $-0.61 * *$ & \\
\hline$(\text { Counter-ideal leader - Actual leader })^{2}$ & 0.22 & 0.06 & $0.23 * *$ & \\
\hline$\Delta R^{2}$ & & & & 0.05 \\
\hline$\Delta F$ & & & & $11.69 * *$ \\
\hline
\end{tabular}


Table 3 Results of multiple regression analysis of respect for leader on squared differences between ideal leader and actual leader, and counterideal leader and actual leader after sample split in Study $1(N=131)$

\begin{tabular}{|c|c|c|c|c|c|c|c|c|}
\hline \multirow[t]{2}{*}{ Respect for leader } & \multicolumn{4}{|c|}{ Subsample $1\left(n_{1}=62\right)$} & \multicolumn{4}{|c|}{ Subsample $2\left(n_{2}=69\right)$} \\
\hline & $B$ & SE $B$ & $\beta$ & & $B$ & SE $B$ & $\beta$ & \\
\hline \multicolumn{9}{|l|}{ Step 1} \\
\hline$(\text { Ideal leader }- \text { Actual leader })^{2}$ & -0.50 & 0.09 & $-0.60 * *$ & & -0.79 & 0.09 & $-0.74 * *$ & \\
\hline$\Delta R^{2}$ & & & & 0.36 & & & & 0.55 \\
\hline$\Delta F$ & & & & $33.30 * *$ & & & & $80.88 * *$ \\
\hline \multicolumn{9}{|l|}{ Step 2} \\
\hline$(\text { Ideal leader }- \text { Actual leader })^{2}$ & -0.46 & 0.09 & $-0.56 * *$ & & -0.63 & 0.11 & $-0.59 * *$ & \\
\hline$(\text { Counter-ideal leader - Actual leader) })^{2}$ & 0.13 & 0.09 & 0.16 & & 0.27 & 0.11 & $0.25^{*}$ & \\
\hline$\Delta R^{2}$ & & & & 0.02 & & & & 0.04 \\
\hline$\Delta F$ & & & & 2.12 & & & & $6.44 *$ \\
\hline
\end{tabular}

Note: Sample split on mean of (Ideal leader - Counter-ideal leader) ${ }^{2}$

$* p<0.05$. ** $p<0.01$

Method

\section{Participants}

Once again, to obtain a heterogeneous sample, we recruited participants via the panel community of sozioland.de. When recruiting, however, we ensured that different panel members were addressed than for the first study, meaning that across studies none of the respondents overlapped. A total of 136 participants completed the survey. All of the participants indicated that they currently reported to a specific leader. Again, a slight majority of the sample was female (54\%). Average participant age was 37.58 years $(S D=10.44)$. Almost $29 \%$ of participants had a university or college degree, and around $69 \%$ had completed professional degrees or other vocational training. Total work experience (i.e., time in employment after completion of first degree) averaged 16 years $(S D=10.13)$ with an average of five personally experienced leaders $(S D=3.47)$, of whom an average of $24 \%$ were female. Overall, participants were employed in more than 20 different industries. All in all, and despite completely different respondents, it can be gathered that the sample's demographics are very similar to the first sample's demographics.

\section{Measures}

To assess the degree to which participants perceived their leaders to match their ideal and counter-ideal leader values, we used the same independent measures as described in Study 1. This time, however, we applied the traditional sixpoint answering scale developed by Schwartz et al. (2001).

Participants' vertical respect for their leaders was measured with the same scale as in Study 1 (van Quaquebeke and Brodbeck 2008; van Quaquebeke et al. 2011).
Participants' identification with their leaders was measured using Mael and Ashforth's (1992) six-item organizational identification scale adapted to the current leader as the target of identification (cf. van Dick et al. 2004). The scale reflects the sense of unity that subordinates feel with their leaders. For example: "When someone criticizes my leader, it feels like a personal insult," or "When I talk about my leader, I usually say 'we' rather than 'he or she.'" Responses were given on a 5-point scale with endpoints "disagree" and "agree" respectively.

\section{Analyses}

As in Study 1, we assigned the 21 items of each version of the PVQ to the related four higher order value types. To assess the leaders' congruence on ideal and counter-ideal leader values, we computed the Euclidian distance scores within each value type and then summed them up.

To test Hypotheses 1 through 4, we conducted a twostep multiple regression analysis. To test Hypothesis 5, we again split the sample at the overall mean of the congruence score between ideal leader- and counter-ideal values.

\section{Results}

Table 4 presents descriptives and scale intercorrelations. Again, the overall scores for ideal and current leader values are positively associated $(r=0.47, p<0.01)$. Moreover, the overall scores for ideal and counter-ideal leader values correlate negatively $(r=-0.34, p<0.01)$. Again, these relationships leave room for unique contributions with respect to our main hypotheses (cf. van Quaquebeke et al. 2010).

Table 5 shows that for both outcomes, both predictors remain significant when simultaneously entered into the 
Table 4 Descriptive statistics and correlations for Study $2(N=136)$

\begin{tabular}{|c|c|c|c|c|c|c|c|c|c|c|}
\hline & $M$ & $S D$ & 1 & 2 & 3 & 4 & 5 & 6 & 7 & 8 \\
\hline 1. Ideal leader & 4.09 & 0.51 & $(0.73)$ & - & - & - & - & - & - & - \\
\hline 2. Counter-ideal leader & 3.00 & 0.61 & $-0.33 * *$ & $(0.75)$ & - & - & - & - & - & - \\
\hline 3. Actual leader & 3.97 & 0.61 & $0.47 * *$ & -0.07 & $(0.75)$ & - & - & - & - & - \\
\hline 4. $(\text { Ideal leader }- \text { Actual leader })^{2}$ & 6.23 & 9.82 & 0.03 & 0.02 & $-0.42 * *$ & $(-)$ & - & - & - & - \\
\hline 5. $(\text { Counter-ideal leader - Actual leader })^{2}$ & 16.45 & 12.27 & $0.35 * *$ & $-0.43 * *$ & $0.50 * *$ & $-0.31 * *$ & $(-)$ & - & - & - \\
\hline 6. $(\text { Ideal leader }- \text { Counter-ideal leader })^{2}$ & 22.17 & 13.36 & $0.37 * *$ & $-0.37 * *$ & 0.05 & $0.45^{* *}$ & $0.55^{* *}$ & $(-)$ & - & - \\
\hline 7. Respect for leader & 3.36 & 0.99 & $0.18 *$ & -0.05 & $0.44 * *$ & $-0.50 * *$ & $0.59 * *$ & 0.08 & $(0.90)$ & - \\
\hline 8. Identification with leader & 2.63 & 0.80 & $0.22 * *$ & -0.03 & $0.40 * *$ & $-0.35 * *$ & $0.42 * *$ & 0.02 & $0.56^{* *}$ & $(0.78)$ \\
\hline
\end{tabular}

Note: Cronbach's alphas are indicated in parentheses

$* p<0.05$. ** $p<0.01$

Table 5 Results of multiple regression analysis of respect for and identification with leader on squared differences between ideal leader and actual leader, and counter-ideal leader and actual leader in Study $2(N=136)$

\begin{tabular}{|c|c|c|c|c|}
\hline & $B$ & SE $B$ & $\beta$ & \\
\hline \multicolumn{5}{|l|}{ Respect for leader } \\
\hline \multicolumn{5}{|l|}{ Step 1} \\
\hline$(\text { Ideal leader }- \text { Actual leader })^{2}$ & -0.50 & 0.07 & $-0.50 * *$ & \\
\hline$\Delta R^{2}$ & & & & 0.25 \\
\hline$\Delta F$ & & & & $45.57 * *$ \\
\hline \multicolumn{5}{|l|}{ Step 2} \\
\hline$(\text { Ideal leader }- \text { Actual leader })^{2}$ & -0.35 & 0.07 & $-0.35^{* *}$ & \\
\hline$\left(\right.$ Counter-ideal leader - Actual leader) ${ }^{2}$ & 0.48 & 0.07 & $0.48 * *$ & \\
\hline$\Delta R^{2}$ & & & & 0.21 \\
\hline$\Delta F$ & & & & $52.20 * *$ \\
\hline \multicolumn{5}{|l|}{ Identification with leader } \\
\hline \multicolumn{5}{|l|}{ Step 1} \\
\hline$(\text { Ideal leader }- \text { Actual leader })^{2}$ & -0.30 & 0.07 & $-0.36^{* *}$ & \\
\hline$\Delta R^{2}$ & & & & 0.13 \\
\hline$\Delta F$ & & & & $20.51 * *$ \\
\hline \multicolumn{5}{|l|}{ Step 2} \\
\hline$(\text { Ideal leader }- \text { Actual leader })^{2}$ & -0.21 & 0.06 & $-0.26 * *$ & \\
\hline$(\text { Counter-ideal leader - Actual leader })^{2}$ & 0.28 & 0.06 & $0.34 * *$ & \\
\hline$\Delta R^{2}$ & & & & 0.11 \\
\hline$\Delta F$ & & & & $0.65^{* *}$ \\
\hline
\end{tabular}

Note: $* p<0.05 . * * p<0.01$

regression equation. In addition, the $R^{2}$ change between step 1 and step 2 is significant for both outcomes, suggesting that the addition of a leader's match of counterideal leader values explains a unique amount of variance beyond the match of ideal leader values. Thus, our Hypotheses 1 to 4 were again supported, replicating the results from Study 1.

Again, to assess whether the obtained effects can be explained by content overlap between ideal and counterideal values, we split our sample and divided the participants into those whose ideal and counter-ideal leader values showed minor differences in content and those whose ideals and counter-ideal leader values showed major differences in content $\left(n_{1}=70 ; n_{2}=66\right)$. Next, we calculated the previous regression analyses again but separately for each subsample. For the subsample where congruence between ideal and counter-ideal values is high, Table 6 shows that only the leader's match of ideal values (for respect for leaders) and the leader's match of counterideal values (for identification with leaders) remain significant separately but not together, when both predictors are simultaneously entered into the regression equation. By 
Table 6 Results of multiple regression analysis of respect for and identification with leader on squared differences between ideal leader and actual leader, and counter-ideal leader and actual leader after sample split in Study $2(N=136)$

\begin{tabular}{|c|c|c|c|c|c|c|c|c|}
\hline & \multicolumn{4}{|c|}{ Subsample $1\left(n_{1}=70\right)$} & \multicolumn{4}{|c|}{ Subsample $2\left(n_{2}=66\right)$} \\
\hline & $B$ & SE $B$ & $\beta$ & & $B$ & SE $B$ & $\beta$ & \\
\hline \multicolumn{9}{|l|}{ Respect for leader } \\
\hline \multicolumn{9}{|l|}{ Step 1} \\
\hline$(\text { Ideal leader - Actual leader })^{2}$ & -0.27 & 0.11 & $-0.29 *$ & & -0.76 & 0.10 & $-0.70 * *$ & \\
\hline$\Delta R^{2}$ & & & & 0.09 & & & & 0.50 \\
\hline$\Delta F$ & & & & $6.38^{*}$ & & & & $63.83 * *$ \\
\hline \multicolumn{9}{|l|}{ Step 2} \\
\hline 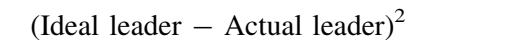 & -0.25 & 0.10 & $-0.27 * *$ & & -0.44 & 0.11 & $-0.41 * *$ & \\
\hline$(\text { Counter-ideal leader }- \text { Actual leader })^{2}$ & 0.39 & 0.10 & $0.43 * *$ & & 0.48 & 0.11 & $0.45^{* *}$ & \\
\hline$\Delta R^{2}$ & & & & 0.18 & & & & 0.11 \\
\hline$\Delta F$ & & & & $16.85^{* *}$ & & & & $18.43 * *$ \\
\hline \multicolumn{9}{|l|}{ Identification with leader } \\
\hline \multicolumn{9}{|l|}{ Step 1} \\
\hline 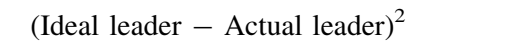 & -0.41 & 0.09 & -0.06 & & -0.48 & 0.10 & $-0.53 * *$ & \\
\hline$\Delta R^{2}$ & & & & 0.00 & & & & 0.28 \\
\hline$\Delta F$ & & & & 0.22 & & & & $25.30 * *$ \\
\hline \multicolumn{9}{|l|}{ Step 2} \\
\hline${\text { (Ideal leader }- \text { Actual leader }^{2}}^{2}$ & -0.03 & 0.09 & -0.05 & & -0.24 & 0.12 & $-0.27 *$ & \\
\hline$(\text { Counter-ideal leader - Actual leader })^{2}$ & 0.17 & 0.09 & $0.24 *$ & & 0.36 & 0.12 & $0.40^{* *}$ & \\
\hline$\Delta R^{2}$ & & & & 0.06 & & & & 0.09 \\
\hline$\Delta F$ & & & & $4.04 *$ & & & & $9.24 * *$ \\
\hline
\end{tabular}

Note: Sample split on mean of (Ideal leader - Counter-ideal leader) ${ }^{2}$

$* p<0.05$. ** $p<0.01$

contrast, both predictors remain significant when simultaneously entered into the regression equation for the subsample with little congruence between ideal and counterideal values. In addition, the $R^{2}$ change between step 1 and step 2 is significant for both outcomes, suggesting that the addition of a leader's match of counter-ideal leader values explains a unique amount of variance beyond the match of ideal leader values when participants' ideal and counterideal values comprise substantially different contents. Thus, Hypothesis 5 is also supported.

\section{General Discussion}

The two studies presented here continue van Quaquebeke et al.s' (2010) initial research on the effects of ideal and counter-ideal leader values on followers' responses toward their leaders. We showed that both positive and negative value orientations exhibit largely independent affects on followers' responses to their leaders. An important extension to previous research is that we found these effects to be stronger the more the contents of followers' ideal and counter-ideal leader values differed from each other. Moreover, while previous research has focused on a rather simple conceptualization of ideal and counter-ideal values, we employed an elaborated value assessment instrument along different value dimensions. In that sense, our studies confirm the theoretical reasoning that ideal and counterideal leader values are not just situated on opposing poles of the same value type, but that counter-ideal leader values comprise a non-redundant layer in relation to ideal leader values (see van Quaquebeke et al. 2010).

For future studies, it seems worthwhile to further explore potential moderators that cause ideal and counter-ideal values to affect attitudes and behavior. Indeed, although value systems are seen as coherent and stable, contextual cues may increase the accessibility or importance of one or the other value layer (Maio et al. 2003). Thus, it might be important to gain insights into the specific contexts that activate and provide salience to either ideal or counter-ideal values (cf. Brewer 1991; Sorrentino et al. 2007). For example, perhaps ideal values influence people more in situations that involve approaching a desirable end state, whereas counter-ideal values might exert more influence in contexts involving avoidance of undesirable outcomes. Although this suggestion seems intuitive, further research is needed to explore the potential influence of contextual moderators on the effects of both value orientations. 
In summary, the notion of two value orientations, ideal and counter-ideal values, as independent forces deepens our understanding of the content and functioning of value systems. The exploration of their antecedents, consequences, and interrelation appears to be a promising area for further study.

\section{Limitations}

The present research is, of course, not without limitations. Although we were able to directly compare the content of participants' ideal and counter-ideal leader values on a predetermined dimensional value space, the relationship between both value types was not completely non-redundant (see van Quaquebeke et al. 2010). While the shared variance does not necessarily indicate that both value orientations are related on a content level, i.e., exact opposite poles on one dimension, the intercorrelation does suggest that their representation in practice is not completely independent. While we did not predict that both value orientations would be completely independent in content, their intercorrelation nevertheless raises an array of research questions regarding when ideal and counter-ideal values are related and when not.

Another potential shortcoming pertains to the common source nature of our data (see Podsakoff et al. 2003). While it should be noted that any common source bias should have worked against finding an independent significant effect of ideal and counter-ideal leader values and thus made it more difficult to find support for our hypotheses, future research may extend our hypotheses to external source data. Indeed, particularly rates of employee turnover or leaders' ratings of followers' efforts would be variables of high concern for the applied context. While we do not expect a different pattern, it would nevertheless be interesting to investigate the effect sizes of leaders' matches of ideal and counter-ideal values for such outcomes.

\section{Practical Implications}

The notion that ideal and counter-ideal values have distinct impact on followers' responses toward their surroundings has important implications for organizational practice. Our findings suggest that organizations and leaders alike should address both value orientations to portray a more complex picture that employees can use to assess where they stand and potentially bond more strongly than they would on the basis of ideal values alone (Kristof 1996; Kristof-Brown et al. 2005; Meglino and Ravlin 1998; Verquer et al. 2003). Naturally, there is the possibility that followers share the organization's assessment of ideal values but not the organization's assessment of counter-ideal values. Such "non-fit" might spur a discussion on what one does and does not want to stand for, or, in the worst case, even lead to employee turnover (cf. Sims and Kroeck 1994). The latter could be regarded as a healthy screening process whereby only people who fully identify with the organization or the leader will stay. However, in most cases, discussion should suffice. We believe there is potential in promoting such discussions of what organizations and leaders do not want to stand for (cf. Murphy 1988) especially because this seems to be a blind spot in today's organizational vision and mission statements.

Open Access This article is distributed under the terms of the Creative Commons Attribution Noncommercial License which permits any noncommercial use, distribution, and reproduction in any medium, provided the original author(s) and source are credited.

\section{References}

Alwin, D. F. (2010). How good is survey measurement? Assessing the reliability and validity of survey measures. In P. Marsden \& J. D. Wright (Eds.), Handbook of survey research (Vol. 2, pp. 405-436). Bingley, UK: Emerald Group Publishing Limited.

Alwin, D. F., \& Krosnick, J. A. (1991). The reliability of survey attitude measurement: The influence of question and respondent attributes. Sociological Methods and Research, 20, 139-181.

Aron, A., Aron, E. N., Tudor, M., \& Nelson, G. (1991). Close relationships as including other in the self. Journal of Personality and Social Psychology, 60, 241-253.

Bardi, A., \& Schwartz, S. H. (2003). Values and behavior: Strength and structure of relations. Personality and Social Psychology Bulletin, 29, 1207-1220.

Bilsky, W., Janik, M., \& Schwartz, S. H. (2010). The structural organization of human values-evidence from three rounds of the European Social Survey (ESS). Journal of Cross-Cultural Psychology. doi:10.1177/0022022110362757.

Brewer, M. B. (1991). The social self: On being the same and different at the same time. Personality and Social Psychology Bulletin, 17, 475-482.

Cacioppo, J. T., \& Berntson, G. G. (1994). Relationship between attitudes and evaluative space: A critical review, with emphasis on the separability of positive and negative substrates. Psychological Bulletin, 115, 401-423.

Cacioppo, J. T., Gardner, W. L., \& Berntson, G. G. (1997). Beyond bipolar conceptualizations and measures: The case of attitudes and evaluative space. Personality and Social Psychology Review, $1,3-25$.

Carver, C. S., Sutton, S. K., \& Scheier, M. F. (2000). Action, emotion, and personality: Emerging conceptual integration. Personality and Social Psychology Bulletin, 26, 741-751.

Cattell, R. B. (1957). Personality and motivation: Structure and measurement. New York, NY: World Book.

Danielsson, P. E. (1980). Euclidean distance mapping. Computer Graphics and Image Processing, 14, 227-248.

Dvir, T., Eden, D., Avolio, B. J., \& Shamir, B. (2002). Impact of transformational leadership on follower development and performance: A field experiment. Academy of Management Journal, $45,735-744$.

Heider, F. (1958). The psychology of interpersonal relations. New York, NY: Wiley.

Hemingway, C. A., \& Maclagan, P. W. (2004). Managers' personal values as drivers of corporate social responsibility. Journal of Business Ethics, 50, 33-44. 
Kaplan, K. J. (1972). On the ambivalence-indifference problem in attitude theory and measurement: A suggested modification of the semantic differential technique. Psychological Bulletin, 77, 361-372.

Katz, D. (1960). The functional approach to the study of attitudes. Public Opinion Quarterly, 24, 163-204.

Kristof, A. L. (1996). Person-organization fit: An interactive review of its conceptualizations, Measurement and implications. Personnel Psychology, 49, 1-49.

Kristof-Brown, A. L., Zimmerman, R. D., \& Johnson, E. C. (2005). Consequences of individuals' fit at work: A meta-analysis of person-job, person-organization, person-group, and personsupervisor fit. Personnel Psychology, 58, 281-342.

Krosnick, J. A., \& Fabrigar, L. R. (1997). Designing rating scales for effective measurement in surveys. In L. E. Lyberg, P. Biemer, M. Collins, E. D. de Leeuw, C. Dippo, N. Schwarz, \& D. Trewin (Eds.), Survey measurement and process quality (pp. 14-164). Hoboken, NJ: Wiley.

Krosnick, J. A., \& Presser, S. (2010). Question and questionnaire design. In P. Marsden \& J. D. Wright (Eds.), Handbook of survey research (Vol. 2, pp. 263-314). Bingley, UK: Emerald Group Publishing Limited.

Lord, R. G., \& Brown, D. J. (2001). Leadership, values, and subordinate self-concepts. The Leadership Quarterly, 12, 133-152.

Mael, F., \& Ashforth, B. E. (1992). Alumni and their Alma Mater: A partial test of the reformulated model of organizational identification. Journal of Organizational Behavior, 13, 103-123.

Maio, G. R., \& Olson, J. M. (1994). Value-attitude-behavior relations: The moderating role of attitude functions. British Journal of Social Psychology, 33, 301-312.

Maio, G. R., \& Olson, J. M. (1995). Relations between values, attitudes, and behavioral intentions: The moderating role of attitude function. Journal of Experimental Social Psychology, $31,266-285$.

Maio, G. R., Olson, J. M., Bernard, M., \& Luke, M. (2003). Ideologies, values, attitudes, and behavior. In T. J. Delamater (Ed.), Handbook of social psychology (pp. 283-308). New York, NY: Kluwer Academic.

Meglino, B. M., \& Ravlin, E. C. (1998). Individual values in organizations: Concepts, controversies, and research. Journal of Management, 24, 351-389.

Murphy, P. E. (1988). Implementing business ethics. Journal of Business Ethics, 7, 907-915.

Olson, J. M., \& Maio, G. R. (2003). Attitudes in social behaviour. In M. J. Lerner \& T. Millon (Eds.), Handbook of psychology: Personality and social psychology (pp. 299-325). New York, NY: Wiley.

O'Muircheartaigh, C., Krosnick, J. A., \& Helic, A. (1999). Middle alternatives, acquiescence, and the quality of questionnaire data. Paper Presented at the American Association for Public Opinion Research annual meeting, St. Petersburg, FL.

Podsakoff, P. M., Podsakoff, N. P., MacKenzie, S. B., \& Lee, J.-Y. (2003). Common method biases in behavioral research: A critical review of the literature and recommended remedies. Journal of Applied Psychology, 88, 879-903.

Posner, B. Z. (2010). Another look at the impact of personal and organizational values congruence. Journal of Business Ethics, 97, 535-541.

Rodin, J. M. (1978). Liking and disliking: Sketch of an alternative view. Personality and Social Psychology Bulletin, 4, 473-478.

Rohan, M. J. (2000). A rose by any name? The values construct. Personality and Social Psychology Review, 4, 255-277.

Rokeach, M. (1973). The nature of human values. New York, NY: Free Press.

Rotter, J. B. (1954). Social learning and clinical psychology. Englewood Cliffs, NJ: Prentice-Hall.
Schwartz, S. H. (1992). Universals in the content and structure of values: Theoretical advances and empirical tests in 20 countries. In M. P. Zanna (Ed.), Advances in experimental social psychology (Vol. 25, pp. 1-65). New York, NY: Academic Press.

Schwartz, S. H. (1994). Are there universal aspects in the structure and contents of human values? Journal of Social Issues, 50, $19-46$.

Schwartz, S. H. (2005). Robustness and fruitfulness of a theory of universals in individual human values. In A. Tamayo \& J. B. Porto (Eds.), Valores e comportamento nas organizaçôes [Values and behavior in organizations] (pp. 56-95). Petrópolis, BRA: Vozes.

Schwartz, S. H. (2006). A theory of cultural value orientations: Explications and applications. Comparative Sociology, 5, 137-182.

Schwartz, S. H., Melech, G., Lehmann, A., Burgess, S., \& Harris, M. (2001). Extending the crosscultural validity of the theory of basic human values with a different method of measurement. Journal of Cross-Cultural Psychology, 32, 519-542.

Sims, R. L., \& Kroeck, K. G. (1994). The influence of ethical fit on employee satisfaction, commitment and turnover. Journal of Business Ethics, 13, 939-947.

Smith, E. R., Coats, S., \& Walling, D. (1999). Overlapping mental representations of self, in-group, and partner: Further response time evidence and a connectionist model. Personality and Social Psychology Bulletin, 25, 873-882.

Snyder, M., \& Cantor, N. (1979). Testing hypotheses about other people: The use of historical knowledge. Journal of Experimental Social Psychology, 15, 330-342.

Snyder, M., \& Swann, W. B., Jr. (1978a). Behavioral confirmation in social interaction: From social perception to social reality. Journal of Experimental Social Psychology, 14, 148-162.

Snyder, M., \& Swann, W. B., Jr. (1978b). Hypothesis-testing processes in social interaction. Journal of Personality and Social Psychology, 36, 1202-1212.

Sorrentino, R. M., Seligman, C., \& Battista, M. E. (2007). Optimal distinctiveness, values, and uncertainty orientation: Individual differences on perceptions of self and group identity. Self and Identity, 6, 322-339.

Suar, D., \& Khuntia, R. (2010). Influence of personal values and value congruence on unethical practices and work behavior. Journal of Business Ethics, 97, 443-460.

van Dick, R., Wagner, U., Stellmacher, J., \& Christ, O. (2004). The utility of a broader conceptualization of organizational identification: Which aspects really matter? Journal of Occupational \& Organizational Psychology, 77, 171-191.

van Quaquebeke, N., \& Brodbeck, F. C. (2008). Entwicklung und erste Validierung zweier Instrumente zur Erfassung von Führungskräfte-Kategorisierung im deutschsprachigen Raum [Development and first validation of two scales to measure leader categorization in German-speaking countries]. Zeitschrift für Arbeits- und Organisationspsychologie, 52, 70-80.

van Quaquebeke, N., Henrich, D. C., \& Eckloff, T. (2007). "It's not tolerance I'm asking for, it's respect!" A conceptual framework to differentiate between tolerance, acceptance and respect. Gruppendynamik und Organisationsberatung, 38, 185-200.

van Quaquebeke, N., Kerschreiter, R., Buxton, A. E., \& van Dick, R. (2010). Two lighthouses to navigate: Effects of ideal and counter-ideal values on follower identification and satisfaction with their leaders. Journal of Business Ethics, 93, 293-305.

van Quaquebeke, N., van Knippenberg, D., \& Brodbeck, F. C. (2011). More than meets the eye: The role of subordinates' selfperceptions in leader categorization processes. The Leadership Quarterly, 10, 367-382.

van Quaquebeke, N., Zenker, S., \& Eckloff, T. (2009). Find out how much it means to me! The importance of interpersonal respect in 
work values compared to perceived organizational practices. Journal of Business Ethics, 89, 423-431.

Verplanken, B. (2004). Value congruence and job satisfaction among nurses: A human relations perspective. International Journal of Nursing Studies, 41, 599-605.

Verplanken, B., \& Holland, R. W. (2002). Motivated decision making: Effects of activation and self-centrality of values on choices and behavior. Journal of Personality and Social Psychology, 82, 434-447.
Verquer, M. L., Beehr, T. A., \& Wagner, S. H. (2003). A metaanalysis of relations between person-organization fit and work attitudes. Journal of Vocational Behavior, 63, 473-489.

Yik, M. S. M., \& Tang, C. S. (1996). Linking personality and values. Personality and Individual Differences, 21, 767-774.

Yukl, G. A. (2010). Leadership in organizations (7th ed.). Englewood Cliffs, NJ: Prentice Hall. 